\title{
Skin Graft Harvesting and Donor Site Selection
}

\author{
Yusuf Kenan Coban, Ahmet Hamdi Aytekin \\ and Göktekin Tenekeci \\ Inonu University, Medical Faculty, Plastic Reconstructive \\ and Aesthetic Surgery Department, \& Burn Unit, Malatya \\ Turkey
}

\section{Introduction}

Acute and chronic wounds are characterized by breakdown of the integrity of the soft tissue envelope surrounding any portion of the body. Flaps and grafts are the two main surgical procedures utilized to repair soft tissue loss. A simple skin graft applied as a thin layer harvested with a dermatome, a scalpel or a special knife may provide a durable coverage. A free skin graft is a piece of skin that has been completely separated from its local blood supply and transferred to a wound at another site, where it must establish new vascular connections through the recipient bed to survive. Skin grafts usually are the first consideration when primary wound closure cannot be achieved. This is true especially for deep burns of wide body areas.(Rudolph R, Ballantyne DL. Skin grafts. In: McCarthy JG, ed. Plastic Surgery. Philadelphia: Saunders; 1990:221-274) A skin graft would be contraindicated, if inosculation from the recipient bed is unreliable with repeated motion or trauma to the area, or in wound infection (Paletta CE, Pokorny JJ, Rumbolo P. Skin grafts. In: Mc- Carthy JG, ed. Plastic Surgery. Philadelphia: Saunders Elsevier; 2006:293-316.)

\section{Historical perspective regarding to skin grafting}

Sir Astley Cooper removed skin from an amputed thumb and used it for stump defect covarage in 1817 (Tiersch C : Über Hautverplanzung. Verh Dtsch Ges Chir 15-17, 1886). Nevertheless skin grafting was not fully accepted for clinical use untill the last quarter of the 19th century. Reverdin was first to draw attention to the technique by successfully performing small pinch grafts in 1972 (Reverdin JL: De la greffe epidermique. Arch Gen Med 19:276;555, 703, 1972.) In 1874, Thiersch extended the use of the pinch graft using large sheets of thin skin grafts to cover the wounds (Tiersch C : Über Hautverplanzung. Verh Dtsch Ges Chir 15-17, 1886.) Blair and Brown (1929) first used the term "intermediate splitthicknes graft" (Blair VP, Brown JB: Use and uses of large split skin grafts of intermediate thickness. Surg Gynecol Obstet 49: 82-97, 1929.) Afterwards, Padgett described a technique for thick skin grafting (Padgett EC. Skin grafting of the burned patient. Plast Reconstr Surg. 2(4): 368-74, 1946). Skin grafting has been the most commonly used technique for reconstruction of cutaneous defects over the last decades. 


\section{Techniques of harvest in different types of skin grafts}

Skin grafts may be physically in one of these three forms; meshed, sheet (unmeshed), pinch/punch. Each type of skin graft has its own harvesting technique. A preoperative plan and surgical judgement is necessary for determining which type of graft will be used. Full thickness skin grafts include all skin appendages, the epidermis and full-thickness of dermis, and splitt-thickness skin graft include a superficial portion of dermis together with epidermis and some of the skin appendages. Many techniques of skin grafting require little experience and only basic surgical equipment. A classification of skin grafts according to depth is seen in Table 1.

\begin{tabular}{|l|l|l|}
\hline Name & Thickness (mm) \\
\hline Split thickness & Thin (Thiersch-Ollier) & $0.15-0.3$ \\
\hline & Intermediate (Blair-Brown) & $0.3-0.45$ \\
\hline & Thick (Padgett) & $0.45-0.6$ \\
\hline Full thickness & (Wolfe-Krause) & $>0.6$ \\
\hline
\end{tabular}

Table 1. Classification of skin grafts according to depth

\subsection{General principles for skin grafting}

Grafting should be done only onto a well-vascularised viable wound surface, such as granulating tissue. Whether the impairments to wound healing and closure are local or systemic, they must be addressed appropriately. Proper wound preparation certainly determines the success of skin grafting. Apropriate debridement is necessary for wound bed preparation. Debridement by hydrosurgical, biological and chemical methods has been reported (Meaume S.Methods of non surgical debridement of wounds in 2011.:Soins 752:4447; 2011). Simple metallic sponges of the sort used in the kitchens which can be sterilized easily are effective for intraoperative surgical debridement. Simple wiping of the wound surface may be adequate enough to remove debris, especilally granulation tissue and soft eschar. Optimizing the patient's medical condition before surgical closure of a wound can mean the difference between a succesfull outcome and an undesirable one. A delay in grafting a suboptimal wound is also good surgical judgment.

\subsection{Splitt thickness skin graft}

Split-thickness skin grafts (STSG) can be harvested rapidly by using a mechanical dermatome. The donor site will heal because the whole of this epidermis can regenerate from deeper parts of the dermis which has left behind on ground. During the harvets by using a harvesting apparatus (dermatome), the donor site should be stabilized and fixed in order to opimise the procedure. The technique of skin grafting is often learned and practiced today using electric or air-powered dermatomes the manuplation of which doesn't require any skill when compared to the harvest by free hand knives.

\subsubsection{Types of dermatomes}

A dermatome is a surgical instrument used to produce thin slices of skin from a donor site and is the main tool for skin graft harvesting. Dermatomes can be operated either manually or electrically. The use of different types of safety razors as a dermatome has been described by some authors. Goullian (1968) constructed a skin grafts set from a weck straight razor by 
adding a fixed handle and a choice of interchangeable space setters to cut different thickness of grafts.(Goullian D.A new economical dermatome Plast Reconst Surg 42: 85, 1968) Snow described the use of a shick injector razor (Snow JW. Safety razor dermatome Plast Reconstr Surg 41: 184, 1968). Shoul (1966) modified a gillette safety razor by filling out the central strut of the safety guard using another blade as a skim. (Shoul M.Skin grafting under local anesthesia using a new safety razor Am J Surg 112.959, 1966) These old- fashioned instruments and shaving blades are difficult to obtain today.

Manual dermatomes are also known as hand-held dermatomes. Occasional users are more likely to use the hand-held knife where adjustment of depth is more difficult. Though most modern graft knives, e.g. the Humby knife and the modified Watson knife, possess an adjustment facility, the appropriate setting is usually determined by eye-balling. Humby skin grafting knife is the most popular. Disadvantages of hand-held knives are harvesting of grafts with irregular edges and grafts of variable thickness. Additonally, its lenght makes many areas inaccessable to harvest skin grafts which poses another disadvantage (Figure 1). This is especially true in infants where the convexity of limbs allows grafts after only an inch wide. In fact with the narrow dermatome (modified safety razor, sober hand dermatome) one can take skin graft practically from anywhere on the body. Use of single blade for coverage of mild to moderate defects is sufficient while the very large defects may require more. The simplicity of the narrow dermatome machine is such that skin grafting can be done by every surgeon. The dermatome is hold firmly against the tightly hold skin at a predetermined angle and the graft of the desired lenght is harvested quickly. Lubrication and a tonque depressor facilitate even harvesting of STSG. Use of a semipermeable membrane in STSG donor site before harvesting has been described for minimising trauma to the graft. (Sams HH, McDonalds MA, Stasko T.Usefull adjunct to harvest split-thickness skin grafts. Dermatol Surg:30(12pt 2): 1591-1592, 2004).
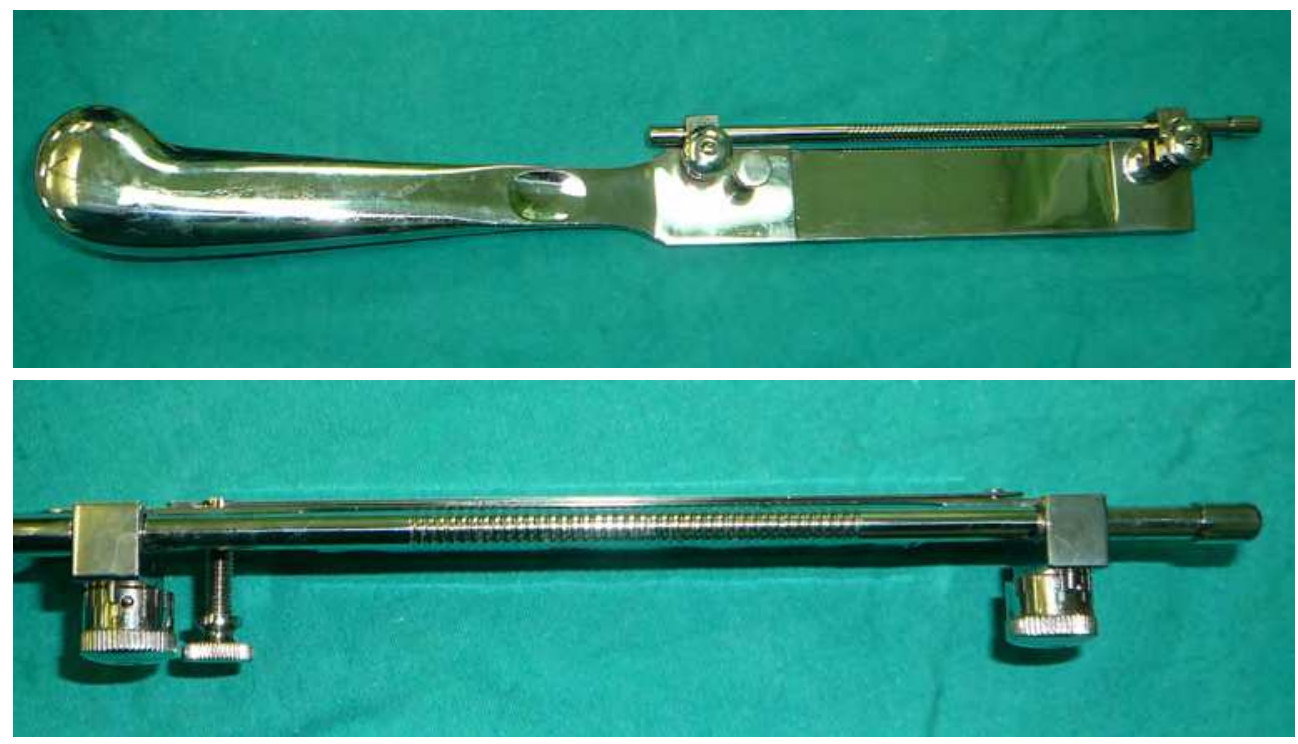

Fig. 1. An example of hand dermatome (schink type): frontal view (top) and lateral view showing Skin Graft thickness adjustment mechanism (bottom). 
Electrical dermatomes are better for cutting out thinner and larger strips of skin with a more homogenous thickness. Dermatomes which were operated by air pressure, such as Brown or Zimmer dermatome, achieved higher speed and precision. Since an electrical dermatomes require electrical energy supply through an electrical cable. It is impractical to sterilize those cable during the operation. Humeca developed a new dermatome for free handed harvesting skin graft with a predetermined thickness of about 0,25 mm. (FIGURE 2).

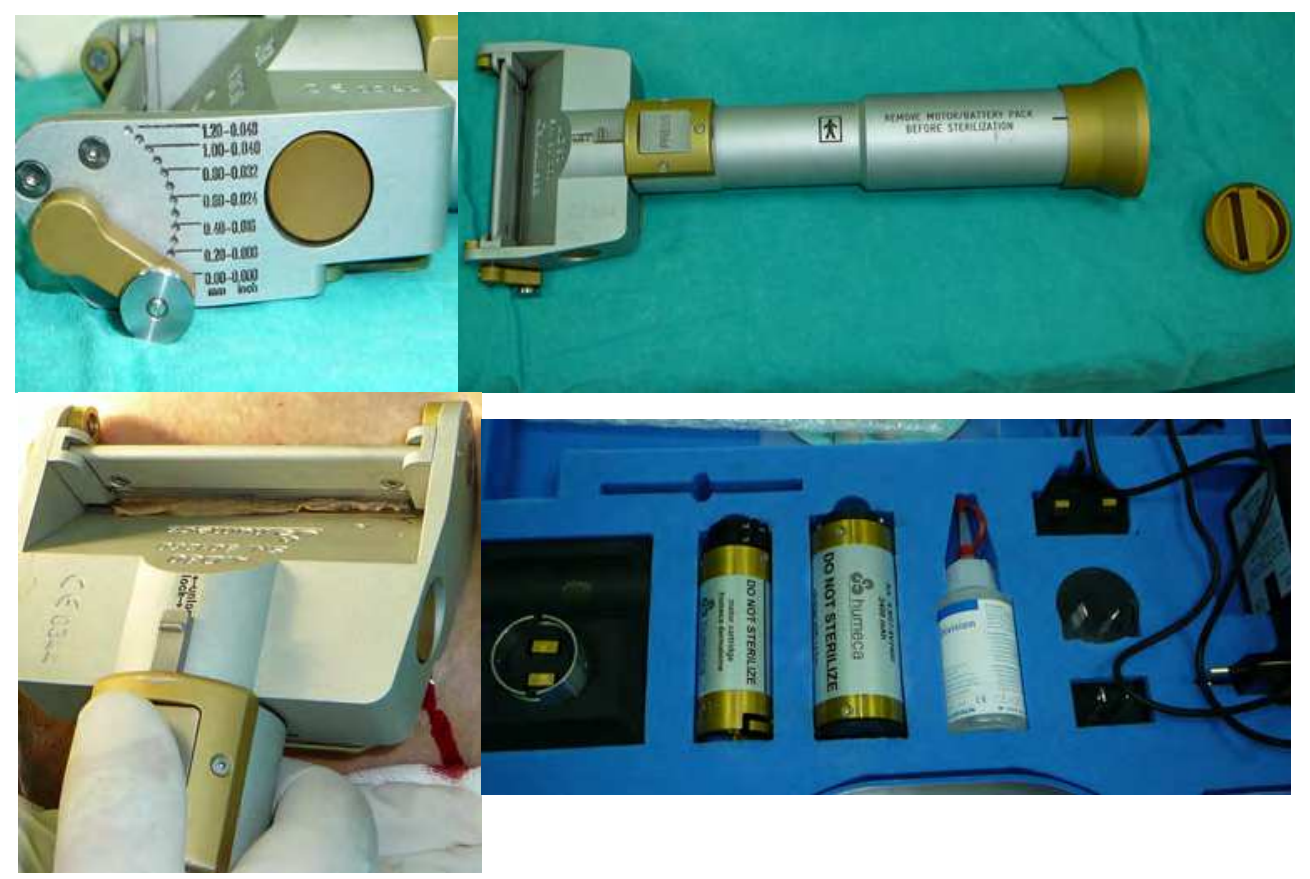

Fig. 2. Humeca electrical dermatome, whole body of cordless electrical dermatome (top right), justification site (top left), easily harvesting STSG (bottom left), and rechargeable batteries with its charging unit (bottom right).

\subsubsection{Graft expansion}

Expansion techniques are used to speed up the epithelialization process while diminishing the need for total amount of graft to be harvested. Various ways to expand grafts have been described including pinch grafts, meshing and micrografting (Meek technique) are among these ways. An expanded graft presents a larger cumulative perimeter through which epithelial outgrowth can proceed.

\subsubsection{Meshing}

Meshing is the term used for slitting a sheet graft and stretching it to open up prior to transplantation. This method of grafting has wide application in the treatment of burns and large contaminated wounds. Meshing ratios greater than $1: 3$ can be difficult to handle, as the skin curls on itself. When larger expansion ratios are desired, it is recommended to use meek micrograft technique for faster healing in body regions like thorax and abdomen. A 
well-known type of mesher contains circular blades and requires the use of grooved plastic carriers (Figure 3). By using such an instrument the blades are forced under pressure to roll over the grooved carrier, thus cutting the graft at locations where the blades contact the carrier. Conventional skin graft carriers have a groove pattern of straight lines from the left to the right under a certain angle. Humeca introduced V-shaped groove pattern which prevents distortion during cutting a mesher. Advantage of these $\mathrm{V}$ carriers is to achieve quickly a more regular meshed grafts.

Humeca supplies two diferent expansion ratios $(1: 1,5$ and $1: 3)$ and one perforation carrier (1:1 ratio). (Humeca Mesher and V- carries.Properties and instructions for use; www.humeca.nl/humeca-mesher) Mesh grafts are expanded by a mechanical device and are used to cute multiple slits in the graft to be stretched. Grafts can be meshed at ratios of 1:1,5 - 1: 4 (FIGURE 4).

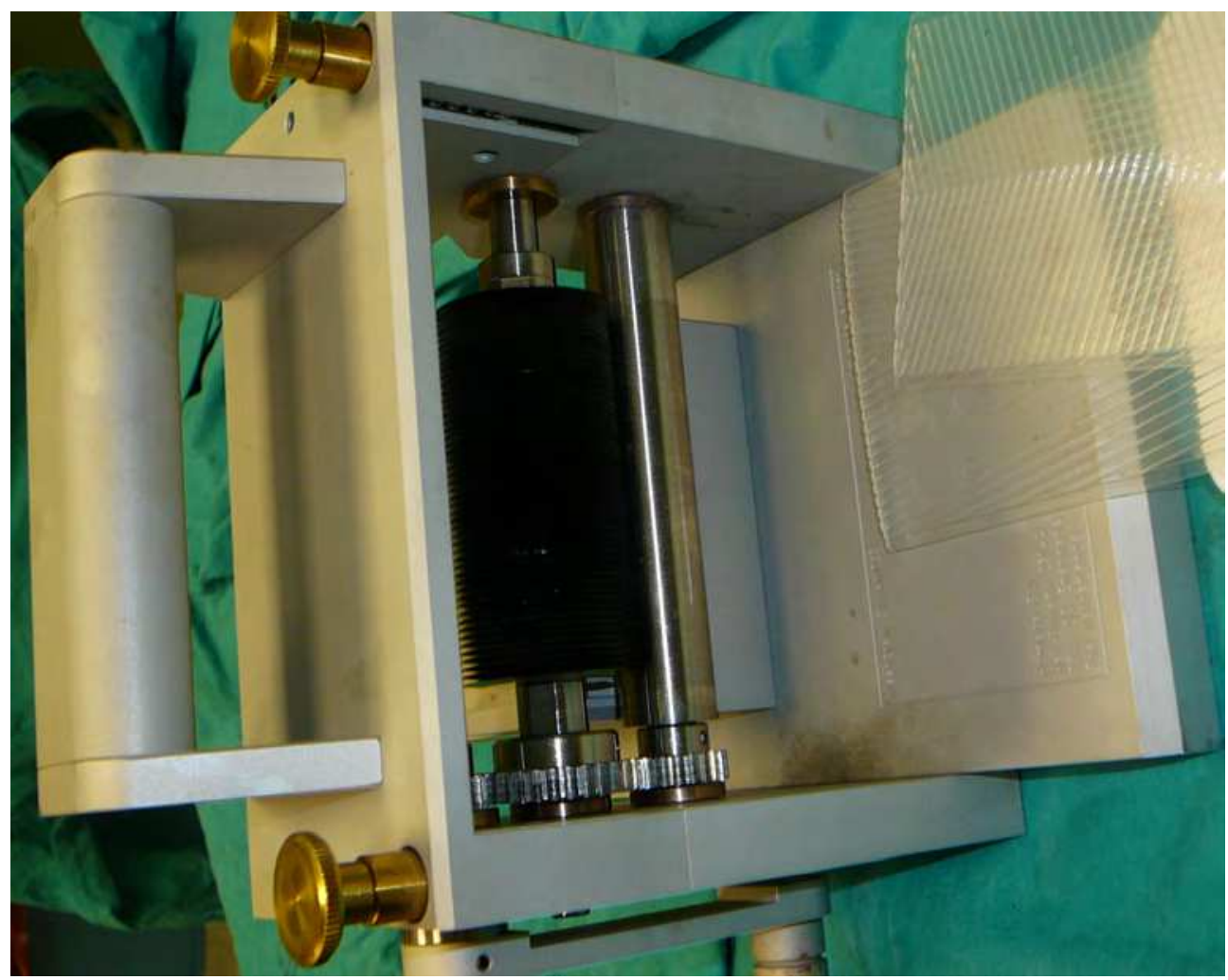

Fig. 3. Two different types of the humeca v-carries (6.V10 -1.5 and 6.V10-3.0, thickness 1.0 $\mathrm{mm}$ and expansion ratio 1.5 and 3 ).

Meshing allows the leakage of serum and blood from wound, minimizing the risk formation of hematomes or seromas that could compromise graft survival. Meshed grafts can also be useful to cover larger surface areas by means of stretching and expanding. 


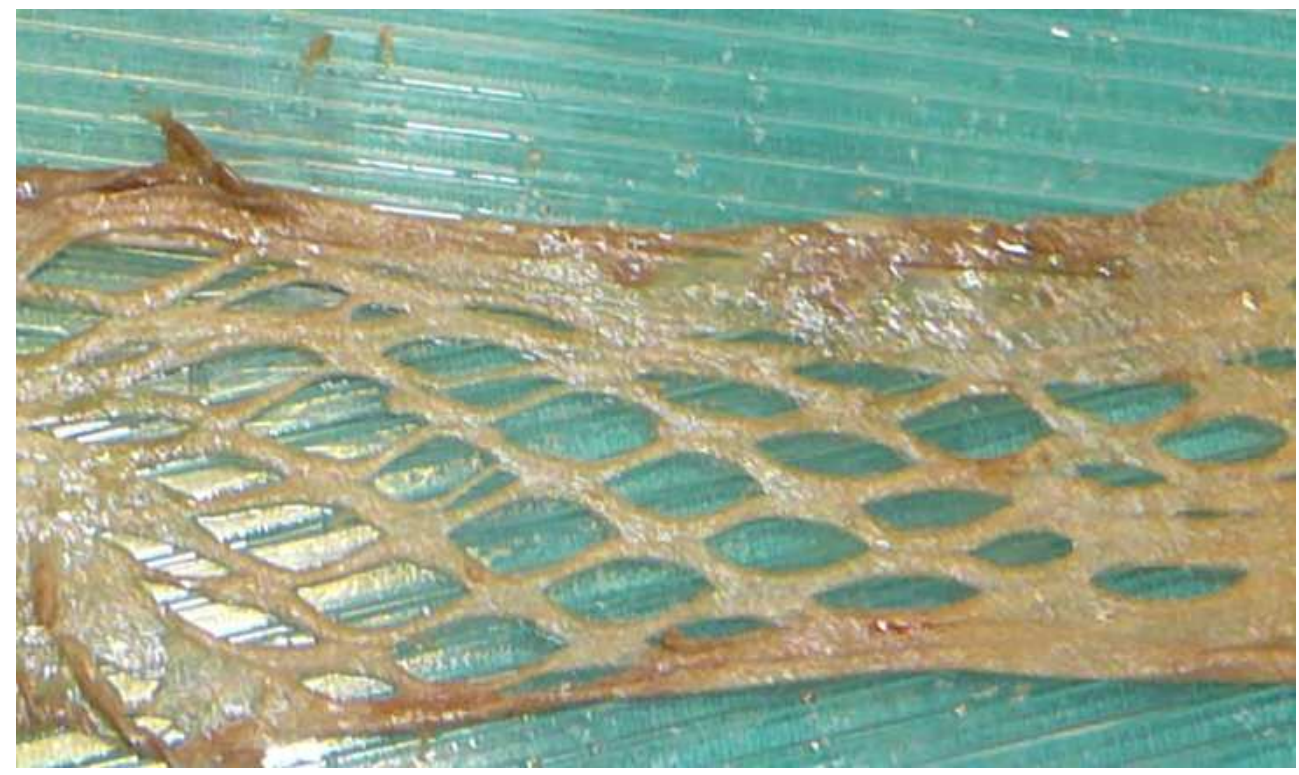

Fig. 4. Meshed skin graft at ratio of 1:3 is seen.

\subsubsection{Meek technique}

Meek (1958) described a technique for expanding a small piece of skin graft with a dermatome in 1958 ( Meek CP, Successful microdermagrafting using the Meek-Wall microdermatome - Am. Surg. vol. 29, pp. 61,1958$)$. This technique was later modified by other authors ( Taner C, Vabdeput JF and Olley JF. The mesh skin graft, Plast Reconstr Surg 34 ; 287-292, 1964 and Kreis RW, Mackie DP, Hermans RP and Vloemans AR. Expansion technique for skin grafts: comparison between mesh and Meek island (sandwiched-) grafts, Burns 20:; 39-42, 1994) The Meek technique of skin expansion is efficient and effective in covering an open wound, particularly when there is a paucity of skin graft donor sites. Meshing of the graft was achieved by passing the carrier that housed the cork so that it was secured in a grille, when passed through the cutting machine. This device (Meek-Wall dermatome) was equipped with 13 circular blades that cut the graft into 14 strips of skin each $3 \mathrm{~mm}$ in width. In order to fabricate 196 pieces of micro-sized skin graft, each measuring $3 \mathrm{~mm} \times 3 \mathrm{~mm}$, the carrier block containing the 14 strips of skin was rotated by $90^{\circ}$ and then passed through the cutting machine again (FIGURE 5). The the cut graft by using Meek technique was already placed on to a base which is elastic and has a speciality of preventing recoiling. 


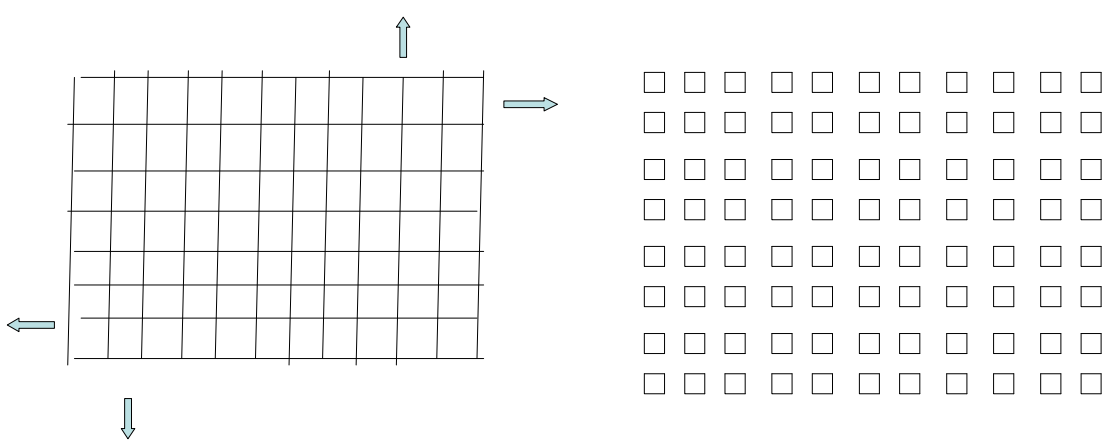

Fig. 5. Vertically and horizontally parelel cuts with following traction in two different directions expands the graft into multiple square mini skin grafts.

The cut grafts were transferred to another carrier, made of polyamide gauze with aluminum foil backing, by removing the cork plate, the epidermal surface of the graft being sprayed with adhesive. Peeters and Hubens showed that the MEEK technique the required graft donor site area is about half of that required with meshing. (Peeters R, Hubens A, The mesh skin graft - true expansion rate - Burns, vol. 14 (3); 239-24 , 1988). In patients with more than $\% 50$ of fullthickness body skin surface loss, the use of modified meek skin grafting technique application for body areas except face, neck and hand regions with an expansion ratio of 1:4 and 1:6 has been succesfully reported.( Raff T, Hartmann B, Wagner H, Germann G. Experience with the modified Meek technique. Acta Chir Plast. 38 (4): 142 - 146, 1996)

\subsubsection{Sheet grafts}

Sheet grafts where the superficial part of skin taken from another part and sliced are STSGs and harvested by a special instrument which is called as dermatome, whereas FTSGs are obtained with scalpel. Sheet grafts are applied without altering following harvest. STSG sheet grafts are usually applied to neck and face areas in where meshed grafts should not be used due to aesthetic concerns. (FIGURE 6). Sheet grafts are STSGs and they can be in there forms; thin, intermediate and thick..

\subsection{Full thickness skin grafting}

Full thickness grafts transfer all skin appendages and nerve endings except those sweat glands located in the subcutaneous tissue and some of Vater-Pacini corpuscles of palmar and plantar skin. ( Lever WF: Histology of skin. pp 9-45. In Lever WF, Shaumburg-Lever G (eds) : Histhopathology of the skin 5th ed.JB Lippincott, Philadelphia 1975. ) FTSG are especially useful for the repair of defects of the nasal tip dorsum ala lateral nasal sidewall, hands, eyelids and ear. Wound contraction is minimal and adnexal structures mostly are harvested together with the graft. An FTSG donor site should be planned in an elliptical shape to simplify direct closure. After an apropriate size has been determined, an ovoid of skin is excised from predetermined area with the axis in the direction of minimal tension. The wound is closed in a standart fashion, undermining the edges as necessary to achieve approximation. It is sometimes difficult to determine how much skin will be required. Templates can be prepared using the paper in which the glove is wrapped. FTSGs transfer all of the skin appendages and nerve endings except those sweat glands located in the 
subcutaneous tissue and some of the Vater-Pacini corpuscles of palmar and plantar skin. There are two techniques for harvesting FTSGs. In the meticulous technique where a sharp dissection is done, only the skin may be obtained. Second one can be described as rough technique. After the incision the predetermined graft donor site, graft can be harvested easily and rapidly by inclusion of subcutaneous fat tissue (Figure 7 and 8).
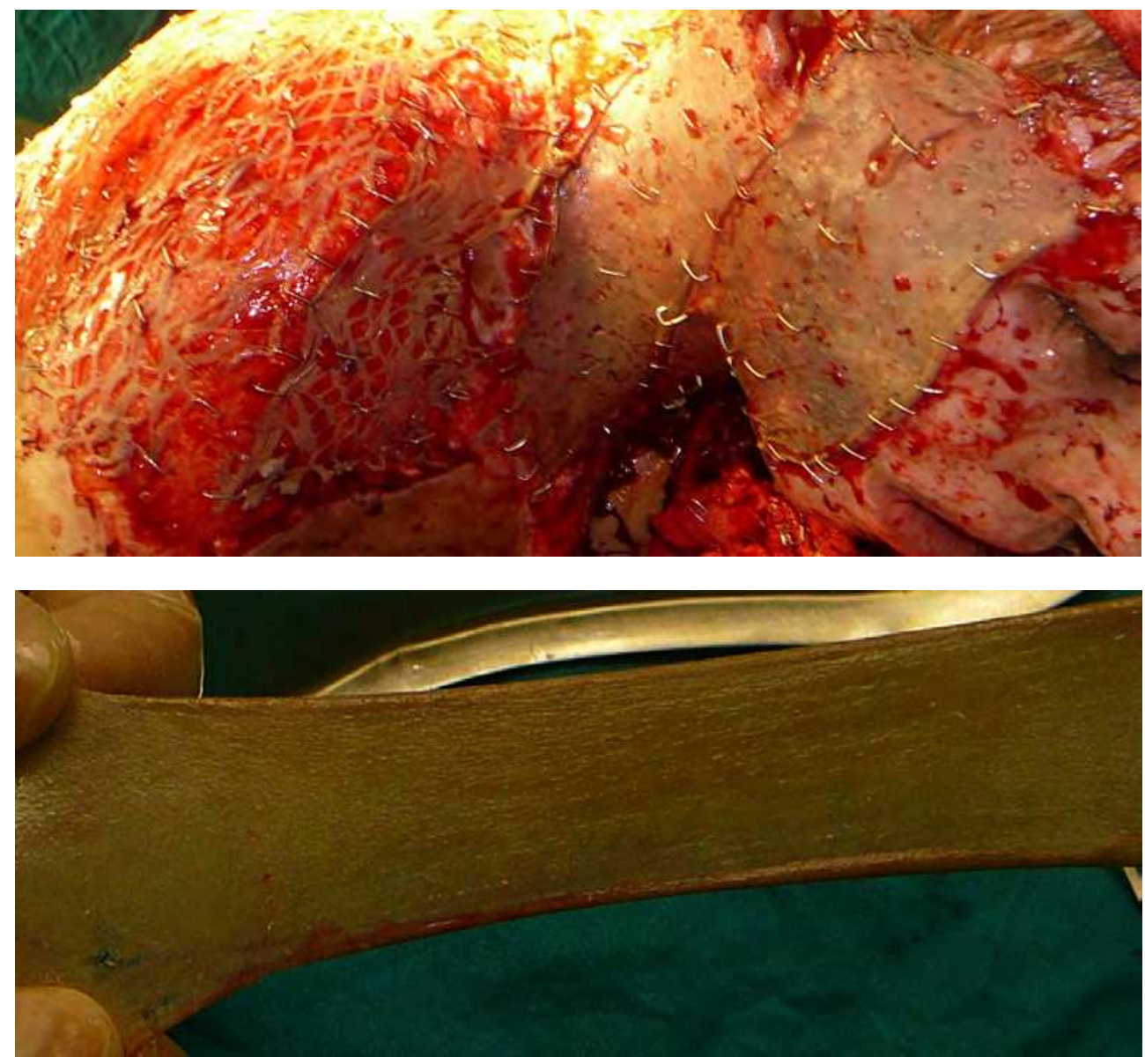

Fig. 6. Note that sheet grafts are applied to neck and face, whereas meshed grafts are other body regions where aesthetics are not primary concerns (Top). Note that some remaining elastic properties of thick STSG is clearly observed (bottom)

In the rapid technique where the skin is harvested with its subcutaneous attachments, there will be need of a following defatting process, since those structure may prevent graft vascularisation. Easily harvested with a scalpel, defatting or thinning the dermis increases the chance of "graft take."FTSGs are commonly harvested from the inguinal region, flank or from the postauricular area. These donor sites can be closed primarily, care should be taken to select a harvest site that does not contain hair. 


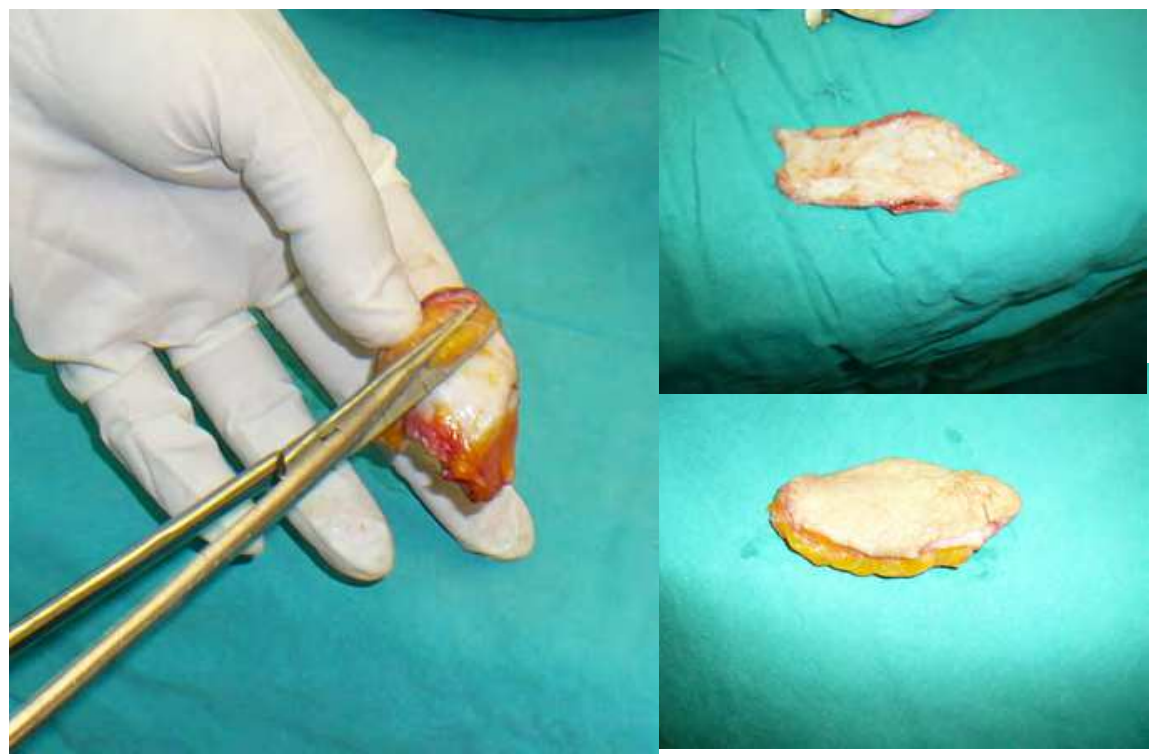

Fig. 7. Rough technique harvesting FTSG: defatting of graft (left), after the procedure (top right) and prior to the procedure the graft including subcutaneous fat (bottom, right).

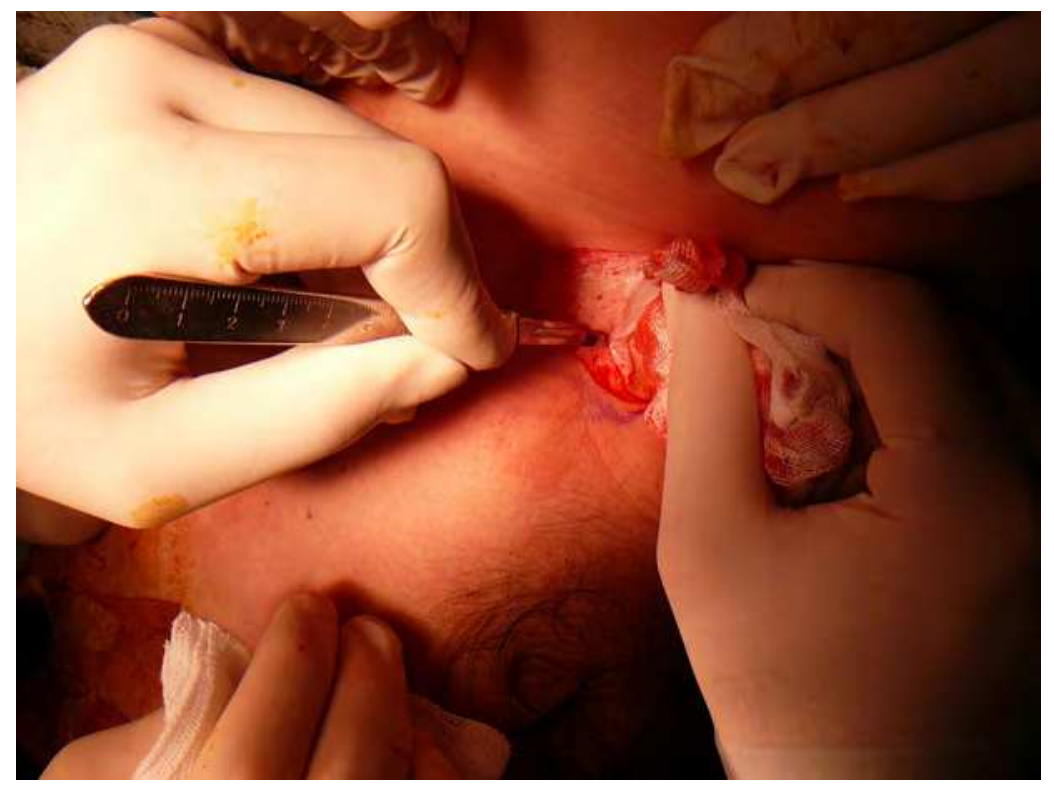

Fig. 8. Meticulouse technique for harvesting FTSG.

The most important factors affecting graft take are an inadequate recipient debridement, hematoma formation and local infection. In order to optimise these factors, Landau et. Al. 
described the use of negative pressure dressing to prepare graft bed. They found FTSG take was in excess of $90 \%$, even though a large surface area and a contour surface needed resurfacing (Landau A, Hudson DA, Adams K, Geldenhuys S, Pienaar C.Full-thickness skin grafts: Maximising graft take using negative pressure dressings to prepare the graft bed. Ann Plast Surg 60(6); 661-666; 2008)

\subsection{Mini and micro skin grafting}

The instruments required are 1.5 or $1.2 \mathrm{~mm}$ punches, small jeweler's or graft holding forceps, and a small curved tip scissors for mini skin grafting. For micro skin grafting additional tools are spraying device, silver's skin grafting knife and spoon for spreading MSG. Dropper shallow stainless tray, diamond fraises and wire bushes are other useful tools. Although the micrograft technique is labour-intensive, if the expansion needed is at least 1:6, the aesthetic and functional results obtained are comparable to, or better than, those with meshed grafts. Pinch grafts should be full thickness $2-5 \mathrm{~mm}$ in diameter with free spaces of $5-10 \mathrm{~mm}$ between each of the grafts. Punch grafts are obtained by using a punch biopsy instrument, 3-5 $\mathrm{mm}$ in diameter (Figure 9). Pinch and punch grafts can also be called as patch or stamp grafts. Mini punch graft (MPG) may be used in transplantation forrepigmentation surgery of vitiligo, or some minor skin defects (Lahiri K.Evolution and evaluation of autologous mini punch grafting in vitiligo..Indian J Dermatol:54(2); 159-167; 2009).

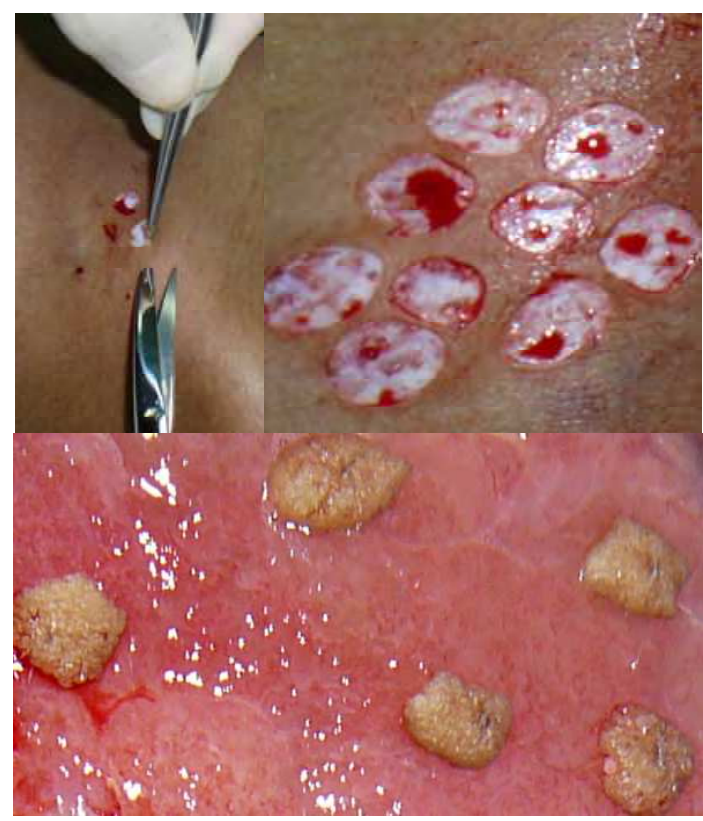

Fig. 9. Mini skin graft harvesting with simple forceps and curved tip scissors(top, , and the donor site after MSG harvesting (right).MSG that applied to a skin defect are shown (bottom).

Hair follicular graft (HFG) is like MPG but it contains a single or more hair follicles and thin sleeve of epidermis and full dermis. HFG can also be called as follicular unit grafts (FU). FU 
is obtained by two methods; first is by using a special extractor and the second one is the method which elliptical harvesting of the donor strip providing more hair with less hair transection per procedure that remains the standard procedure. Although larger punch grafts and scalp flaps may play role in certain cases. FU transplantation is the culmination of decades of refinements and evolution of hair transplantation techniques. Hair naturally groups in groups of one to four individual follicles seperated by intervening soft tissue. These clumps or groups of hairs are termed follicular units.

The usual donor region is between occipital protuberance and $1 \mathrm{~cm}$ above the top of the ear (FIGURE 10). This donor site can easily be closed primarly.
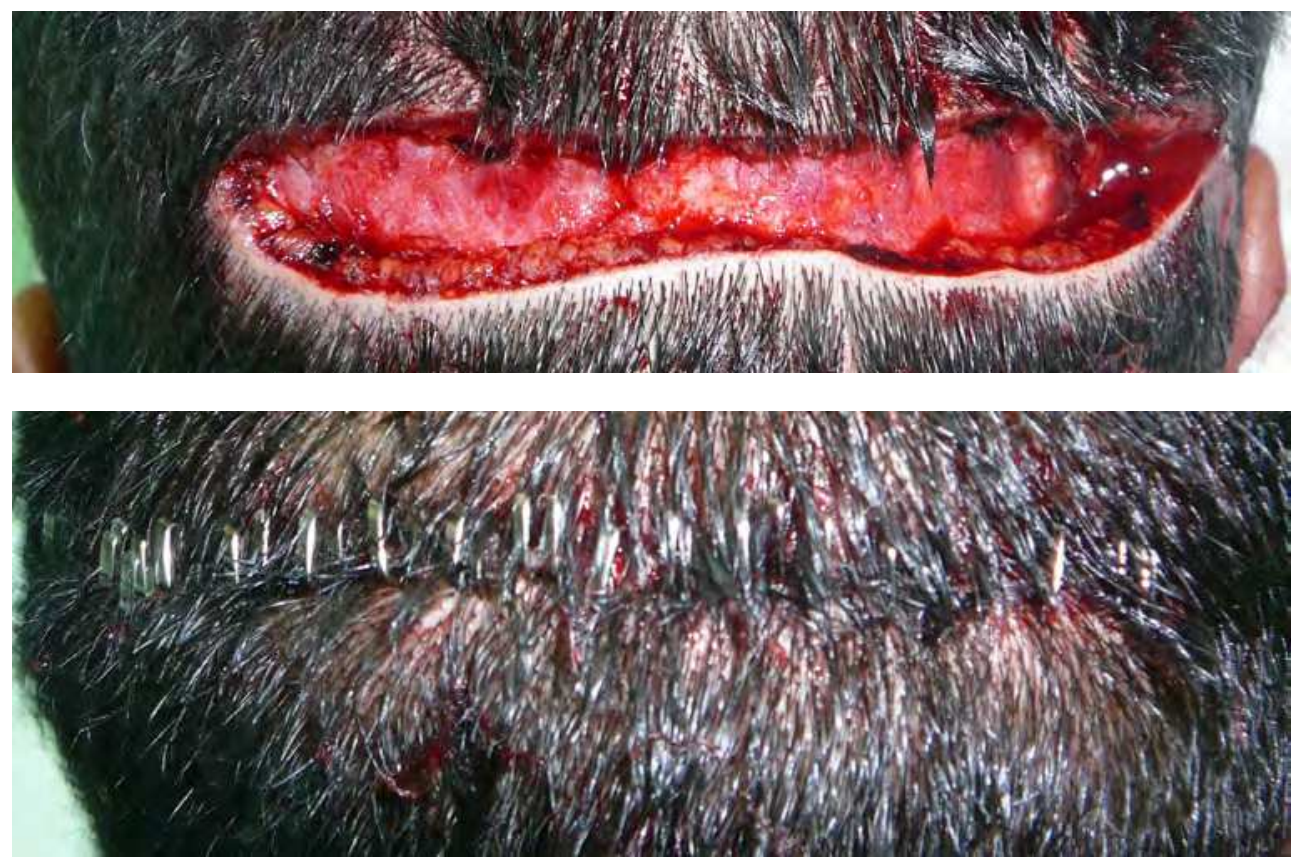

Fig. 10. Posterior occipital donor site : after the harvest (top) and closing the donor site primarly (bottom)

The average density in the posterior scalp is 65- $85 \mathrm{FU}$ per $\mathrm{cm}^{2}$. This is the safest place to harvest hair. The donor ellipse is handed by a surgical assistant and meticulous seperation of follicular goupings is begun using stereomicroscopic disssection. It is preferred greater lenght than width in a donor ellipse to achieve the desired number of follicular grouping. FUextract is the harvesting of individual FU units wtih $1 \mathrm{~mm}$ puches (FIGURE 11).

\subsection{Composite skin grafting}

Donor site selection of composite graft which is composed of multiple structures like skin and cartilage requires a more complicated approach, as defects of aesthetic subunits has its own characteristics and needs a more close attention in the repair process. Good examples of using composite graft are eyelash reconstruction with strip composite eyebrow grafts and alar rim defect repair with composite auricular graft. Strip composite eyebrow graft is the 


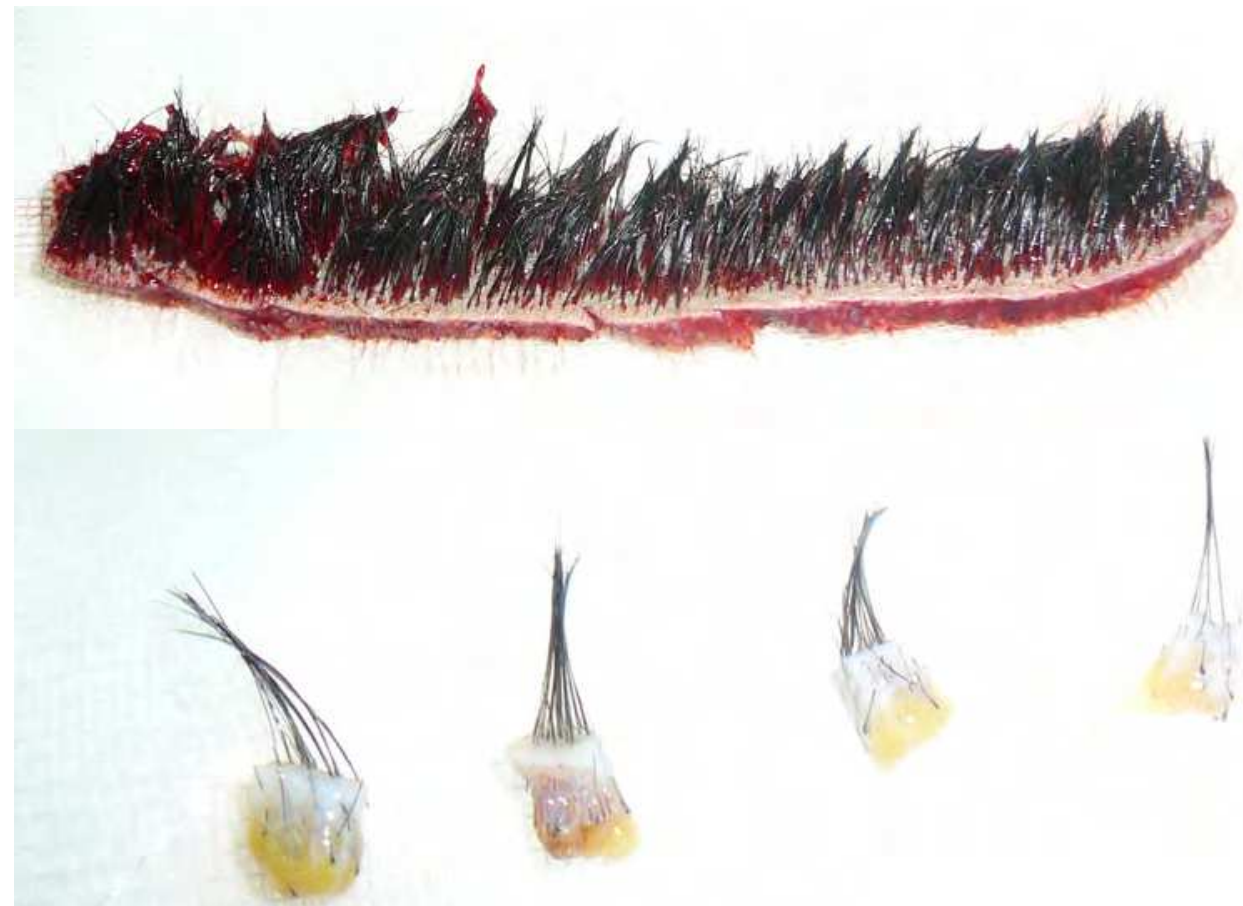

Fig. 11. A strip obtained from occipital donor site (top) and sliced FUs (bottom)

At first, the strip is divided into slices, much like slicing a loaf of bread, then each sliver is divided into individual FUs of 1, 2, 3, 4 -hair grafts (FIGURE 12). Upper limits of transplanted hair follicular unit number changes between 1500- 4500 for each session.

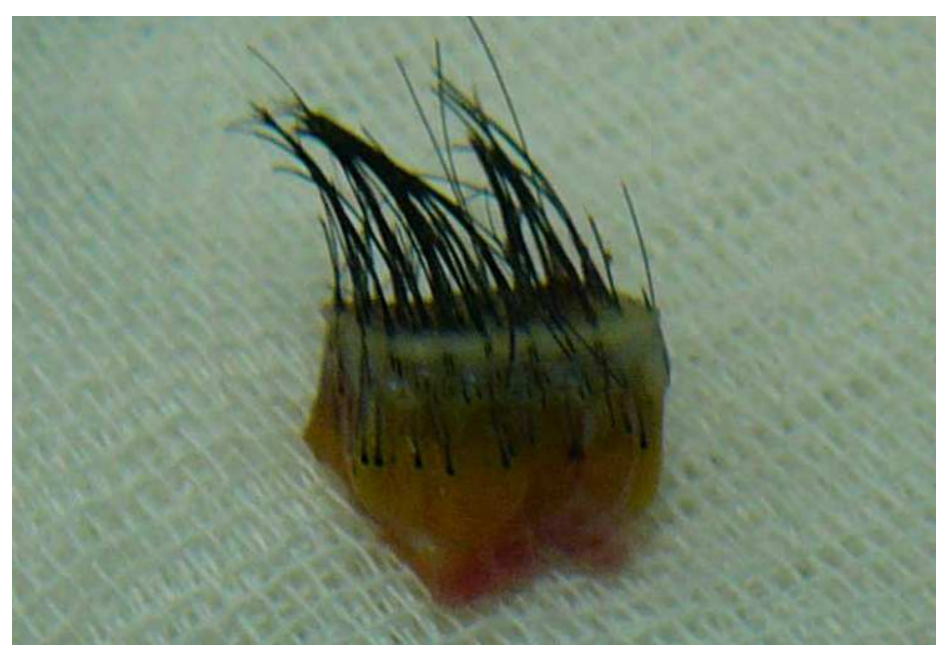

Fig. 12. This HFG is to be scliced into smaller FU grafts. 
most suitable as its properties are very similiar to those of the original eyelash hairs. (Kasai K.Eyelash resonstruction with strip composite eyebrow graft. Head and Neck Surg 60(6);649-651; 2008) (Coban YK, Geyik Y.An ideal composite graft donor site for postburn alar rim deficiencies: root of helix . J Craniofac Surg: 21(4);1246; 2010)

\begin{tabular}{|lll|}
\hline \multicolumn{1}{|c|}{$\begin{array}{c}\text { Types of composite skin } \\
\text { grafts }\end{array}$} & \multicolumn{1}{c|}{ Used for } & \multicolumn{1}{c|}{$\begin{array}{c}\text { Additional content } \\
\text { tissue }\end{array}$} \\
\hline $\begin{array}{l}\text { Strip eyebrow graft } \\
\text { Conchal / helical composite } \\
\text { grafts }\end{array}$ & $\begin{array}{l}\text { Eyelash reconstruction } \\
\text { Alar rim / columella }\end{array}$ & $\begin{array}{l}\text { Subcutaneous fat } \\
\text { Auricular cartilage }\end{array}$ \\
$\begin{array}{l}\text { Scalp punch, pinch } \\
\text { (follicular) grafts }\end{array}$ & $\begin{array}{l}\text { Hair restoration } \\
\text { Strip scalp grafts }\end{array}$ & Subcutaneous fat \\
\hline
\end{tabular}

Table 2. Types of skin composite grafts.

\section{Donor site selection criteria}

The selection of donor site is essential to achieve the best possible outcome. Donor sites, from which the skin grafts are taken, can be virtually anywhere in the body. Main criteria related with donor site selection is about which kind of skin graft is to be used. The importance of clothing styles particularly those swimwear must be considered in selection of donor site. The closer the donor site is to defect, the better the color and texture match. FTSG in general, convex areas of the body are easier to harvest than concave areas. With a very thin STSG the scar at the donor site will be the least pronounced. The anterior thigh provides a large expanse of skin for larger skin grafts. Split-thickness skin graft donor sites are more numerous than those for full-thickness skin grafts, because the former heal spontaneously, mainly by reepithelialization from epidermal appendages found in the residual dermis. Whereas harvesting FTSG from any part of body leaves a donor site scar behind. So when using FTSG hidden donor areas by clothing are usually selected. A graft taken from skin adjacent to the surgical defect, known as Burrow's graft often provides an ideal match with respect to both color and texture. For example, skin taken from nasolabial fold may be used to close small nasal tip defects and may often supply a degree of sebaceous quality. Similarly clavicular skin may be used for a defect of photodamaged area, as this site provides a better color match. The ulnar border of the hypothenar area is an excellent source of small grafts for the fingertips. Preputium may be used as FTSG donor site when circumcision is also planned.(Yıldırım S, Akan M, Akoz T, Tanoglu B.Preputium: an overlooked skin graft donor site. Ann Plast Surg:46(6);\&30-634; 2001).

\subsection{Choice of graft}

Best choice for a skin graft depends on the location of the defect. The actual principle to be cared is the similarity between the donor and recipient site characteristics. The properties that are expected from the grafted skin are the expected aesthetic appearence, the size of defect, donor availability, donor site morbidity. Palmar skin of the instep is the best replacement of the palmar skin of the digit and hand. In other way, plantar defects are usually repaired glabrous skin grafts taken from hypothenar hand regions. (Wu LC, Goutlieb LJ. Glabrous Dermal Grafting: A 12-Year Experience with the Functional and Aesthetic Restoration of Palmar and Plantar Skin Defects Plast.Reconstr. Surg. 116: 1679, 
2005.) It has been shown that medial plantar grafts even in the form of pinch grafts are effective in resurfacing palmar wounds. (Siman R.Medial Plantar Arch Pinch Grafts Are an Effective Technique to Resurface Palmar and Plantar Wounds Ann Plast Surg 2004;53: 256260.) At follow-up all those with plantar skin grafts show excellent color and texture match with adjacent palmar or plantar skin. The graft would be soft, supple, mobile and stable without any pigmentation. Walking and weight bearing has been shown to be smooth.

Another example for choice of graft is decision on glabrous or non glabrous skin grafts. Plantar defects that are to be grafted are reconstructed with split or full thickness skin grafts. If non glabrous skin grafts are used some disadvantages which includes painfull hyperkeratotic build up at the periphery of the grafts ocur. The long standing use of glabrous skin grafts for plantar defects confirms the desirability functional advantage, minimal morbidity of this technique. (Banis JC. Glabrous skin grafts for plantar defects. Foot Ankle Clin 2001:6(4); 827-837).

\subsection{Choice of donor site and its preparation}

Donor sites for full-thickness skin grafts tend to be limited to areas over joint creases or crevices where the donor site can be closed directly after graft harvest. For glabrous skin, hypothenar donor area, wrist crease and plantar arc area are good donor sites. Skin may be harvested from abdomen for facial defect repair, however the color and texture match may be less desirable. Donor sites for the harvest of skin graft include the lumbar and gluteal regions (thick skin), the thighs, and the arms (thin skin). The skin on the ventral, outer, and dorsal aspects of the thigh is classed as intermediate thickness for the purposes of skin grafting; an optimum harvest is $0.35 \mathrm{~mm}$ thick(Ostrovisky NV. Selection of the skin graft thickness with regard to the structure of the donor site skin. Acta Chir Plast; 27: 145-51; 1985). The usable thickness of thigh skin graft varies froma minimum of $0.25 \mathrm{~mm}$ to a maximum of $0.55 \mathrm{~mm}$ in most cases, though in elderly patients or steroid-damaged skin a thinner graft needs to be taken.

In contrast to common sites, the scalp's advantage has been seen primarily for cosmetically satisfying repair of facial defects. An additional important reason for using the scalp as a donor site for split-skin grafts is the patient's postoperative comfort and mobility. Wound healing is quick, the risk of infection is minimal, graft preparation and postoperative care are relatively easy, and the scalp as a source of meshgrafts harbors a reasonably large area for wound coverage. The site has only minimal interference with patients' rehabilitation, and later scar formation is rare. The donor site hidden under regrowing hair is invisible (Weyandt GH, Bauer B, Berens N, Hamm H, Broecker EB. Split-thicknes skin grafting from scalp: The hidden advantage.Dermatol Surg:35;1873-1879; 2009)

If possible use local anesthesia for donor site so that more likely to operate. Use plenty of very dilute local anesthetic for example, donor site is anesthesized with $1 \%$ lidocaine with epinephrine 1:100000 . In addition 10-30 cc of saline is added to produce turgor. The turgor helps with anesthesia, provides hemostasis and reduces transection of hair follicles. If possible use local anesthetic such as 0,4 \% lignocaine with adrenalin and 10-30 cc of saline is added to produce turgor to graft out the skin all over the donor site. This helps hemostasis and reduces transection of hair follicles, when there is a need of hair follicle inclusion into the graft. Any medication that is not essential should be stopped at least 1 week prior to surgery. All smokers should be encouraged to cease cigarette smoking several days prior to surgery and to continue this for at least the first postoperative week. The donor skin is prepared and lubricated in the usual way, tensed using the skin graft boards and the graft taken. Proper skin tensioning is important. 


\subsection{Fixation techniques}

Sutures, staples, or other adhesive agents can be used to affix the skin graft to the recipient bed. he use of stitches is a common method of fixation but it is quite time consuming, difficult to do in the split-thickness graft, very expensive and the stitches must be removed.A "stent" dressing and even the ubiquitous subatmospheric pressure device are intended means of preventing graft separation from the wound resulting from either shear forces or subgraft fluid accumulations. (Hallock GG. Expanded applications for octyl-2cyanoacrylate as a tissue adhesive. Ann Plast Surg.;46:185-189; 2001) Human fibrin sealant (FS) has been proven effective for skin grafting after burn. FS is used as a slow clotting spray (4-5 IU thrombin / ml) (Mittermayr R, Wassermann E, Thurnher M, Simunek M, Redl H.Skin graft fixation by slow clotting fibrin sealant applied as a thin layer. Burns:32:3; 305-311; 2006).

An alternative, especially applicable for large sheet grafts, would be to leave the graft uncovered to allow frequent rolling of fluids from underneath. The use of surgical drape placed over the graft has been recognised, but must be removed at the second or third day[3]M.O. Yenidünya, E. Özdengill and I. Emsen, Split-thickness skin graft fixation with surgical drape, Plast Reconstr Surg 106 (6) (2000), pp. 1429-1430. View Record in ScopusCited By in Scopus (7) when the grafts are not well vascularized and this can lead to failure of the graft. In convex areas skin graft fixation can be done by a simple tie-over dressing (Coban YK. A novel tie-over dressing for circular defects: star tie-over .Burns:33(6);801-802; 2007)

\subsection{Other parameters related to selection of donor site}

Harvesting of an autograft results in a wound in healthy donor skin. Therefore several techniques have been developed to reduce the required surface area of donor skin, especially in FTSG applications of children. In order to obtain large enough FTSG and accomplish primary donor site closure, a prior tissue expansion may be applied the donor site (Canter HI, Igde M, Vargel I, Ozgur F.Repeated tissue expansions on split-thickness skin graft in a patient with neurocutaneous syndrome.J Craniofac Surg:18(3);699-703; 2007).

Some pactical methods are also present in taking grafts like reuse skin graft patches or using freshly generated epithelium as a source of donor site. (Coban YK, Gumus N. Reuse of skin graft patches fort he coverage of skin defects.J Burn Care Res:27(2);234-236; 2006) (Gumus $\mathrm{N}$, Coban YK.Freshly generated epithelium may be a donor site fort he coverage of deep skin defects in the combined skin wounds.Burns:33(5);673-676; 2007).Main logics of these applications are the presence of limited sources of donor sites and concerns on wounding a healthy donor site.Looking for an alternative donor site scalp is a suitable location to achieve STSG. If early repetetive harvesting from the same area is required such as in a burn patients, shortening of healing time and patients mobility are great advantages for this donor site .

\subsection{Limitations of composite grafting}

Composite grafts have limited dimentions and their usage for solving some challenging clinical conditions are also limited. Their usual dimention is about $0,5 \mathrm{~cm}$ (width) $\times 3 \mathrm{~cm}$ (lenght). As they are dependent on recipient blood supply, grafts exceeding dimentions of these limits can not survive. If a long strip graft is to be used, its width must not exceed 0,5 $\mathrm{cm}$. (Coban YK, Geyik Y.An ideal donor site for postburn alar rim deficiencies: root of helix. J Craniofac Surg: 21(4);1246; 2010). 


\section{Future expectations}

Numerous variations such as mesh grafts, cultured epithelial autografts (CEA)and combined allo-autografts techniques have significantly enhanced the therapeutic spectrum of traditional skin graft techniques. In the absence of a dermis, mature fibroblasts secrete collagen into the altered pattern of a scar. The graft can fail to take when CEAs and autografts are applied to a wound surface in poor condition without a dermis. Moreover, there is a risk of poor epithelialization, due to the absence of a dermal component at the recipient site. Therefore, a dermal equivalent is required to overcome this problem. issue engineered skin is a significant advance in the field of wound healing. The translation from scaffolds to instructive three dimentional dermal substitues is not a simple task. New skin substitues for burn care are currently under development. They were developed due to limitations associated with the use of autografts. These limitations include the creation of a donor site which is at risk of developing pain, scarring, infection and / or slow healing.

More complex tissue-engineered skin substitues in which stroma, adipose tissue, capillaries and neurons combined with epithelium are being developed. These products are often a combination of cells, scaffolds and other factors.(Proulx S, Fradette J, Gavuin R, Larouche D, Germain L.Stem cells of the skin and cornea: Their applications in regenerative medicine. Curr Opin Organ Transplant 2010;dec 9.epub.) The application of these new products necessiate generally two-three staged operations to obtain final results.(FIGURE 13) During the past decade skin equivalents have been developed in order to reproduce epidermal and dermal elements in vivo.

A number of approaches were taken in the development of a skin substitute. One solution was to develop an acellular matrix complex that would guide the migration of fibroblasts into a pattern that had dermal-like qualities. Another approach was to expand a small piece of epidermis into a very large transplantable viable autologous-epidermal cell layer through tissue culturing. The third approach was to develop a skin equivalent composed of both a

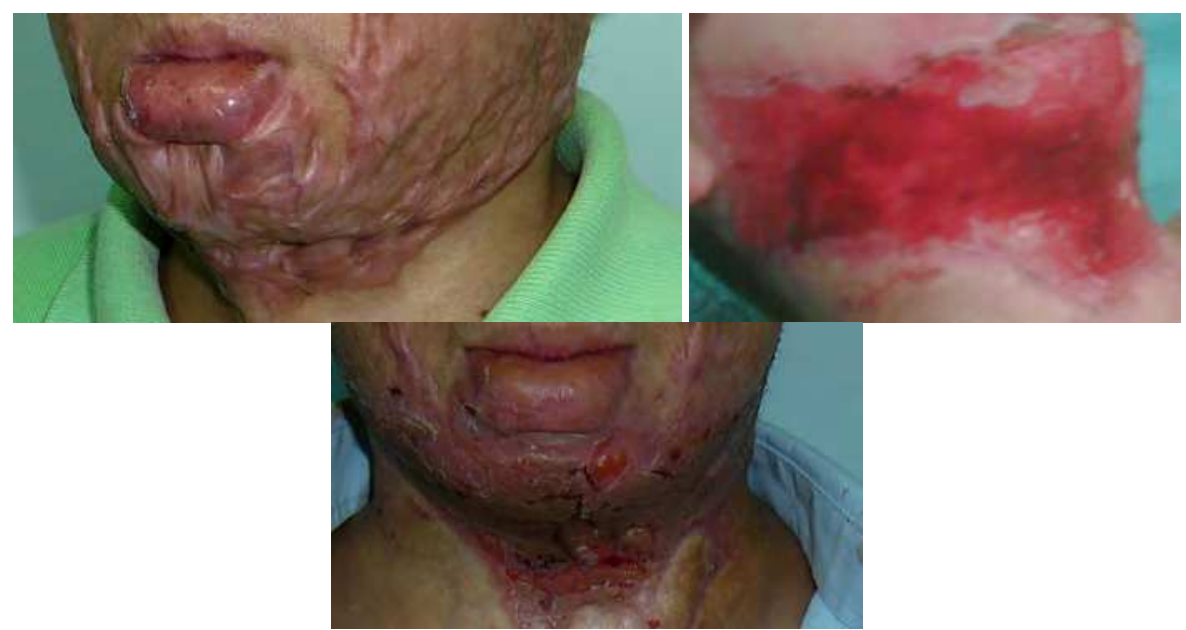

Fig. 13. Hypertrophic scarring due to flame burn injury of mandibular region (Left), welldeveloped granulation after the application of hyalomatrix skin substitute (esterified hyalurinic acid ) for three weeks following to excision of scarred tissues (right), final result with thin STSG for epidermal replacement (centre). 
collagen matrix populated with viable fibroblasts and a dermal equivalent layer that was covered with viable keratinocytes (epidermal layer). Most commercially available products are based on polymer matrices derived from both natural and synthetic sources. The majority of these products are designed to mimic the basic properties of the extracellular matrix. The use of dermal substitutes is increasingly widespread but the outcomes of substitute-asisted healing remain functionally deficient. There seems to be a long way to obtain a perfect skin equivalance that mimicks all structures of dermis and epidermis both aesthetically and functionally.

\section{Conclusion}

Skin grafting has become a technique that is routinely and sometimes preferentially considered as skin replacement for burns, chronic ulcers, skin defects due to other etiologies. In cases in which autologous grafts cannot be performed, skin substitutes have become an attractive alternative. Autologous skin grafts are commonly considered as the gold standard treatment. Availability of autologous grafts is a major obstacle, however, and the search for a manufactured skin replacement seems to be continued.

\section{References}

[1] Banis JC. Glabrous skin grafts for plantar defects. Foot Ankle Clin 2001:6(4); 827-837

[2] Blair VP, Brown JB: Use and uses of large split skin grafts of intermediate thickness. Surg Gynecol Obstet 49: 82-97, 1929.

[3] Canter HI, Igde M, Vargel I, Ozgur F.Repeated tissue expansions on split-thickness skin graft in a patient with neurocutaneous syndrome. J Craniofac Surg 2007:18(3);699703.

[4] 4-Coban YK, Gumus N. Reuse of skin graft patches fort he coverage of skin defects. J Burn Care Res 2006:27(2);234-236.

[5] Coban YK. A novel tie-over dressing for circular defects: star tie-over .Burns 2007:33(6);801-802.

[6] Coban YK, Geyik Y.An ideal donor site for postburn alar rim deficiencies: root of helix. J Craniofac Surg 2010: 21(4);1246.

[7] Goullian D.A new economical dermatome Plast Reconst Surg 42: 85; 1968.

[8] Gumus N, Coban YK. Freshly generated epithelium may be a donor site for the coverage of deep skin defects in the combined skin wounds.Burns 2007:33(5);673-676.

[9] Hallock GG. Expanded applications for octyl-2-cyanoacrylate as a tissue adhesive. Ann Plast Surg. 2001;46:185-189.

[10] Kasai K.Eyelash resonstruction with strip composite eyebrow graft. Head and Neck Surg 2008:60(6);649-651.

[11] Lahiri K.Evolution and evaluation of autologous mini punch grafting in vitiligo..Indian J Dermatol 2009:54(2); 159-167.

[12] Landau A, Hudson DA, Adams K, Geldenhuys S, Pienaar C.Full-thickness skin grafts: Maximising graft take using negative pressure dressings to prepare the graft bed. Ann Plast Surg 2008:60(6); 661-666.

[13] Lever WF: Histology of skin. pp 9-45. In Lever WF, Shaumburg-Lever G (eds) : Histhopathology of the skin 5th ed.JB Lippincott, Philadelphia 1975. 
[14] Meaume S.Methods of non surgical debridement of wounds in 2011.2011:Soins 752:4447.

[15] Mittermayr R, Wassermann E, Thurnher M, Simunek M, Redl H.Skin graft fixation by slow clotting fibrin sealant applied as a thin layer. Burns 2006:32:3; 305-311.

[16] Ostrovisky NV. Selection of the skin graft thickness with regard to the structure of the donor site skin. Acta Chir Plast 1985; 27: 145-51.

[17] Padgett EC. Skin grafting of the burned patient. Plast Reconstr Surg 1946.1947 jul 2(4): 368-74.

[18] Paletta CE, Pokorny JJ, Rumbolo P. Skin grafts. In: Mc- Carthy JG, ed. Plastic Surgery. Philadelphia: Saunders Elsevier; 2006:293-316.

[19] Peeters R, Hubens A, The mesh skin graft - true expansion rate - Burns, vol. 14 (3), pp. 239-24, 1988.

[20] Proulx S, Fradette J, Gavuin R, Larouche D, Germain L.Stem cells of the skin and cornea: Their applications in regenerative medicine. Curr Opin Organ Transplant 2010;dec 9.epub.

[21] Raff T, Hartmann B, Wagner H, Germann G. Experience with the modified Meek technique. Acta Chir Plast. 1996; 38 (4): 142 - 146.

[22] Reverdin JL: De la greffe epidermique. Arch Gen Med 19:276;555, 703, 1972.

[23] Rudolph R, Ballantyne DL. Skin grafts. In: McCarthy JG, ed. Plastic Surgery. Philadelphia: Saunders; 1990:221-274.

[24] Sams HH, McDonalds MA, Stasko T.Usefull adjunct to harvest split-thickness skin grafts. Dermatol Surg 2004:30(12pt 2): 1591-1592.

[25] Shoul M.Skin grafting under local anesthesia using a new safety razor Am J Surg 112.959,1966.

[26] Siman R.Medial Plantar Arch Pinch Grafts Are an Effective Technique to Resurface Palmar and Plantar Wounds Ann Plast Surg 2004;53: 256-260.

[27] Snow JW. Safety razor dermatome Plast Reconstr Surg 41: 184, 1968.

[28] Taner C, Vabdeput JF and Olley JF. The mesh skin graft, Plast Reconstr Surg 34 (1964), pp. 287-292. and Kreis RW, Mackie DP, Hermans RP and Vloemans AR. Expansion technique for skin grafts: comparison between mesh and Meek island (sandwiched-) grafts, Burns 20: 1994; 39-42.

[29] Tiersch C : Über Hautverplanzung. Verh Dtsch Ges Chir 15-17, 1886.

[30] Yildırım S, Akan M, Akoz T, Tanoglu B.Preputium: an overlooked skin graft donor site. Ann Plast Surg 2001:46(6);\&30-634.

[31] Weyandt GH, Bauer B, Berens N, Hamm H, Broecker EB. Split-thicknes skin grafting from scalp:The hidden advantage.Dermatol Surg 2009:35;1873-1879.

[32] Wu LC, Goutlieb LJ. Glabrous Dermal Grafting: A 12-Year Experience with the Functional and Aesthetic Restoration of Palmar and Plantar Skin Defects Plast.Reconstr. Surg. 116: 1679, 2005. 


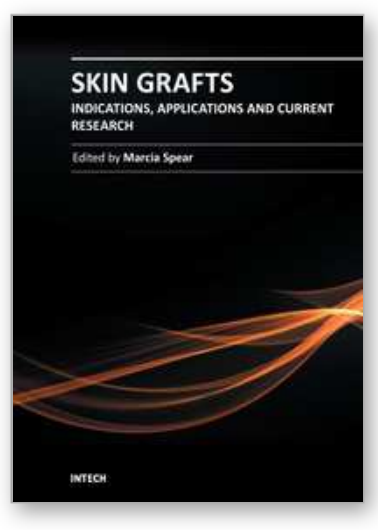

\author{
Skin Grafts - Indications, Applications and Current Research \\ Edited by Dr. Marcia Spear
}

ISBN 978-953-307-509-9

Hard cover, 368 pages

Publisher InTech

Published online 29, August, 2011

Published in print edition August, 2011

The procedure of skin grafting has been performed since 3000BC and with the aid of modern technology has evolved through the years. While the development of new techniques and devices has significantly improved the functional as well as the aesthetic results from skin grafting, the fundamentals of skin grafting have remained the same, a healthy vascular granulating wound bed free of infection. Adherence to the recipient bed is the most important factor in skin graft survival and research continues introducing new techniques that promote this process. Biological and synthetic skin substitutes have also provided better treatment options as well as HLA tissue typing and the use of growth factors. Even today, skin grafts remain the most common and least invasive procedure for the closure of soft tissue defects but the quest for perfection continues.

\title{
How to reference
}

In order to correctly reference this scholarly work, feel free to copy and paste the following:

Yusuf Kenan Coban, Ahmet Hamdi Aytekin and Göktekin Tenekeci (2011). Skin Graft Harvesting and Donor Site Selection, Skin Grafts - Indications, Applications and Current Research, Dr. Marcia Spear (Ed.), ISBN: 978-953-307-509-9, InTech, Available from: http://www.intechopen.com/books/skin-grafts-indicationsapplications-and-current-research/skin-graft-harvesting-and-donor-site-selection

\section{INTECH}

open science | open minds

\section{InTech Europe}

University Campus STeP Ri

Slavka Krautzeka 83/A

51000 Rijeka, Croatia

Phone: +385 (51) 770447

Fax: +385 (51) 686166

www.intechopen.com

\section{InTech China}

Unit 405, Office Block, Hotel Equatorial Shanghai

No.65, Yan An Road (West), Shanghai, 200040, China

中国上海市延安西路65号上海国际贵都大饭店办公楼 405 单元

Phone: +86-21-62489820

Fax: +86-21-62489821 
(C) 2011 The Author(s). Licensee IntechOpen. This chapter is distributed under the terms of the Creative Commons Attribution-NonCommercialShareAlike-3.0 License, which permits use, distribution and reproduction for non-commercial purposes, provided the original is properly cited and derivative works building on this content are distributed under the same license. 